\title{
Bioconcrete Development Using Calcite -Precipitating Bacteria Isolated From Different Sources in Jordan
}

\author{
Suha M. Abudoleh ${ }^{1}$, Amal Al Mahayreh ${ }^{2}$, Aya Al Frejat ${ }^{2}$, Fatima Al Hulaisy ${ }^{2}$, and Sara O. Hamdan ${ }^{3}$ \\ ${ }^{1}$ Faculty of Pharmacy - Isra University \\ ${ }^{2}$ Faculty of Engineering- Civil Engineering Department- Al Tafileh University \\ ${ }^{3}$ Independent Researcher, Amman, Jordan
}

\begin{abstract}
Concrete is considered as the most widely used construction material in the world. However, concrete is exposed to cracks due to different factors like overloads, temperature, shrinkage, earthquakes and others. These cracks reduce the strength, the service life of the structure, and increase the permeability of the concrete. Thus, the importance of "self-healing concrete" is highlighted nowadays, with emphasis on a special type of concrete called bioconcrete, which is a concrete that has the ability to self-heal the microcracks that happen due to overloads. This ability comes from the bacteria used in the concrete mix which have special characteristics such as the ability to live in harsh conditions similar to those found in the concrete environment, in addition to their ability to precipitate calcite (calcium carbonate $\left(\mathrm{CaCO}_{3}\right)$ ), the sealing material in the cracks. This study aims to assess the performance of self-healing Bacillus mycoides incorporated into Portland cement mortar. This bacterium has been isolated from the soil of Fava beans in Jordan. Cracking of specimens was induced by load percent concept after 7 days of curing and tests were performed at 21 days of cracking. The testing scheme for the mortar included bacterial sporulation tests inside mortar specimens, acid fizz test and a compression test. Results demonstrated that self-healing bacteria is a promising technique in minimizing cracking. The rate of healing using bacteria was higher than the bacteria-free negative control.
\end{abstract}

\section{Introduction}

Concrete is the most widely used construction material in the world due to many reasons such as low cost, durability, and strength [1,2]. However, concrete is exposed to cracks that result from different factors like overloads, temperature, shrinkage, earthquakes, etc [3]. These cracks reduce the strength and the service life of the structure and increase the permeability of the concrete [4].

Microcracks are micrometer-scale cracks which do not affect the stability of the structure, but they can spread to form a network of micro- and larger cracks, which may consequently affect the permeability of the concrete, thus allowing water and chemicals to ingress into the mix; this leads to steel corrosion, and eventually the tensile strength will be lost and the structure will fail $[3,5,6]$.

As a result, it is necessary to repair the cracks in order to reduce the permeability and increase the durability of the structure. The current maintenance methods repair the cracks after they happen and spread. They are expensive, time-consuming, and in some cases they are impossible because the cracks are invisible or in locations that cannot be accessed [3,6]. In Europe for example, half of annual construction budgets are allocated to repair works [7].

This has led to the invention of a new technique for sealing cracks in concrete, called "self-healing concrete", which is concrete that can heal itself, an idea that was inspired from the wound healing in the human body [3]. Bioconcrete, a type of self-healing concrete, is cheap and environmentally sustainable which contains self-healing agents without compromising the initial properties of concrete during the mixing phase of concrete or mortar [8].

This new mechanism depends on spore-forming, mineral-producing bacteria originally found in environments with harsh conditions such as soil, rocks, alkaline lakes, etc. [9], thus enabling them to survive in the concrete paste. When cracks appear, bacteria inside the concrete would be activated by the penetrating water and oxygen, and would then precipitate minerals, such as calcite, to fill the cracks.

Various methods have been used to immobilize Bacillus which have successfully led to stabilization of the metabolic activity of the bacteria for a longer time due to decreasing the rate of bacterial activity [10]. One 
of these methods is immobilization of the healing agent via encapsulation; this was not successful due to the cracking [10]. Another method was to use diatomaceous earth (DE) as an immobilizing agent [11]. DE is a natural, soft, siliceous sedimentation with a particle size ranging from $10-200 \mu \mathrm{m}$. DE consists of fossilized remains of diatoms whose skeletons are highly porous, light in weight, and chemically stable and inert [12]. These pores found in diatoms form potential homes for microbes, nutrients, water and oxygen which can ultimately help sustain life [11].

Previous studies have all proven the efficiency of selfhealing concrete in eliminating the cracks that form. The present study builds further on these outcomes; the material used is mortar and the self-healing agent is Bacillus bacteria isolated from various sources such as soil of legumes, fish ponds and multiple locations within the Dead Sea region. These bacteria were chosen to be used in this study because of their high potential in living in strong alkaline environments, their spore-forming abilities, their susceptibility to activation upon exposure to water, and their ability to live in high temperatures, thus eliminating the need for a mobilization agent. The bacteria work as a catalyst by feeding on calcium lactate and producing calcite, the sealing material of the crack. This study also investigates the effect of lowering the $\mathrm{pH}$ level of mortar specimens by replacing a percent of cement with silica fume.

\section{Methodology}

\subsection{Bacterial isolation and characterization}

\subsubsection{Selection of potential sources for bacterial isolation}

Potential isolates with the required characteristics were searched for in samples originating from areas with harsh conditions such as soil from various areas in the Dead Sea region, deep soil sample from normal agricultural land in Amman, soil of legumes, soil samples from Al Karak city and mud of a fish pond in the Dead Sea area.

\subsubsection{Cultivation of bacteria and selection of bacterial colonies}

From each of the previously mentioned soil sources, approximately 1 gram of soil was transferred into $10 \mathrm{ml}$ of nutrient broth with different $\mathrm{pH}$ values (9 and 12) and incubated for 3 days at $37{ }^{\circ} \mathrm{C}$.

After 3 days, each sample was shaken well and the soil particles were given enough time to precipitate. This was followed by dilution via the transfer of $1 \mathrm{ml}$ of the supernatant to $9 \mathrm{ml}$ of sterile normal saline. Then a serial decimal dilution was performed for each sample and each one was diluted up to $10^{-7}$.

One hundred microliters of various dilutions were spread over the surface of nutrient agar in order to check the viability and find isolated colonies of bacteria that were tolerant to the $\mathrm{pH}$ values that it was cultured in. The nutrient agar after that was incubated for $48 \mathrm{~h}$ at $37{ }^{\circ} \mathrm{C}$.

From each soil sample, bacterial colonies were initially chosen and isolated based on differences in colony morphology and color. Each colony was transferred into a separate nutrient agar plate and subcultured 3 times to ensure purity, and for each isolate a numerical code was given.

\subsubsection{Characterization of bacteria}

\subsubsection{Tolerance to $\mathrm{pH} 14$}

Each pure colony was cultured in nutrient broth at $\mathrm{pH} 14$ at $37^{\circ} \mathrm{C}$ for $24 \mathrm{~h}$, and then cultured over nutrient agar to check viability for $24 \mathrm{~h}$.

\subsubsection{Hydrolysis of urea}

Potential isolates that were able to tolerate high $\mathrm{pH}$ levels were cultured over urea base agar supplemented with 5\% urea and incubated for $24 \mathrm{~h}$ at $37{ }^{\circ} \mathrm{C}$ to test their ability to produce urease enzyme.

\subsubsection{Cell morphology and spore formation}

Morphology of potential isolates was examined using Gram stain and the spore-forming ability was tested using the malachite green stain according to the regular microbiology protocol. Specimens were examined using light microscopy at 1000x magnification.

\subsubsection{Thermal stability}

The potential isolates were cultured in nutrient broth and incubated at $70{ }^{\circ} \mathrm{C}$ for $24 \mathrm{~h}$. After the incubation time, the growth of the bacteria was recorded as scores with (-) indicating no growth and $(+)$ indicating growth.

\subsubsection{Calcite formation and acid fizz test}

Each potential isolate was grown in a flask containing $200 \mathrm{ml}$ of mineral salt media (MSM) supplemented with $5 \%$ calcium lactate pentahydrate $\left(\left[\mathrm{CH}_{3} \mathrm{CH}(\mathrm{OH}) \mathrm{COO}\right]_{2} \mathrm{Ca} \cdot 5 \mathrm{H}_{2} \mathrm{O}\right)$ and incubated in an orbital shaker at $100 \mathrm{rpm}$ for 3 days at $37{ }^{\circ} \mathrm{C}$. At the end of the incubation period the culture was transferred to a centrifuge tube, and centrifuged at $5300 \mathrm{rpm}$ for 30 minutes. After collection of the supernatant, calcite production was examined by $\mathrm{CO}_{2}$ gas generation after adding 2 drops of $10 \% \mathrm{HCl}$; the formation of bubbles indicated the presence of calcite.

\subsubsection{Bacterial identification}

Potential isolates were identified using API $50 \mathrm{CH}$ kit (Biomerieux, France) according to manufacturer's protocol. 


\subsection{Bioconcrete}

\subsubsection{Materials}

The cement used is Ordinary Portland Cement type I CEM I $52.5 \mathrm{~N}$ which matches the Jordanian specification (JS 30-1:2007) and the European specification (EN 19712000 ) with a fineness modulus of $365 \mathrm{~m} 2 / \mathrm{kg}$. The sand used was well-graded fine aggregate passing sieve No.8. Tap water and grade 9 silica fume were also required. The precursor used for inducing bacteria to precipitate calcite was calcium lactate. Diatomaceous earth (DE) with a $\mathrm{pH}$ of $9.0-10.5$ and a median particle size of $20-$ 25 microns was used.

\subsubsection{Phase I preparation}

Bioconcrete cubes measuring $5 \mathrm{~cm}^{3}$ were prepared according to regular protocol using the materials found in the proportions in Table 1 with a water/cement+silica ratio of 0.7 . The bacterial type used in the cubes was chosen based on previously carried out pilot studies to determine the bacteria with the highest potential for crack healing. Preparation of the bioconcrete cubes was followed by curing in tap water for 1 week.

Table 1. Phase I Bioconcrete content.

\begin{tabular}{|c|c|c|}
\hline Cube ID & Control & Bioconcrete \\
\hline $\begin{array}{c}\text { Cement } \\
\text { (g) }\end{array}$ & 145 & 145 \\
\hline $\begin{array}{c}\text { Silica fume } \\
\text { (g) }\end{array}$ & 25 & 25 \\
\hline $\begin{array}{c}\text { Water } \\
\text { (ml) }\end{array}$ & 125 & 125 \\
\hline $\begin{array}{c}\text { Sand } \\
\text { (g) }\end{array}$ & 460 & 460 \\
\hline $\begin{array}{c}\text { Calcium } \\
\text { Lactate } \\
\text { (g) }\end{array}$ & 0 & $2.4 \times 10^{10}$ \\
\hline $\begin{array}{c}\text { Bacterial } \\
\text { Load } \\
\text { (CFU/blend) }\end{array}$ & 0 & \\
\hline
\end{tabular}

\subsubsection{Phase I cracking and compression}

Compression test was conducted in accordance with ASTM C109. After curing for 7 days, a cube from each blend (control and bioconcrete) was loaded until failure to determine the ultimate load. Then, each control and bioconcrete cube was exposed to $80 \%$ of its respective ultimate load to induce the formation of microcracks. A group of control and bioconcrete cracked cubes were then immersed in tap water for another three weeks (21 days) to allow the bacteria to begin calcite precipitation and crack healing, while another group of cracked cubes was loaded until failure to assess the compressive strength of cubes that already contained cracks. At the end of the three weeks, each cube was loaded to failure to determine the compressive strength after calcite precipitation.

\subsubsection{Phase II preparation with $D E$}

Bioconcrete cubes with and without DE measuring $5 \mathrm{~cm}^{3}$ were prepared following regular protocol according to the specifications in Table 2 with a water/cement+silica ratio of 0.5 ; the cubes that contained DE were prepared by displacing a portion of the sand with DE. Preparation of the bioconcrete cubes was followed by curing in tap water for 1 week.

Table 2. Phase II Bioconcrete content.

\begin{tabular}{|c|c|c|c|c|}
\hline Cube ID & $\begin{array}{c}\text { Control } \\
-\mathrm{DE}\end{array}$ & $\begin{array}{c}\text { Control } \\
+\mathrm{DE}\end{array}$ & $\begin{array}{c}\text { Bioconcrete } \\
-\mathrm{DE}\end{array}$ & $\begin{array}{c}\text { Bioconcrete } \\
+\mathrm{DE}\end{array}$ \\
\hline $\begin{array}{c}\text { Cement } \\
\text { (g) }\end{array}$ & 425 & 425 & 425 & 425 \\
\hline $\begin{array}{c}\text { Silica fume } \\
\text { (g) }\end{array}$ & 75 & 75 & 75 & 75 \\
\hline $\begin{array}{c}\text { Water } \\
(\mathrm{ml})\end{array}$ & 250 & 250 & 250 & 250 \\
\hline $\begin{array}{c}\text { Sand } \\
(\mathrm{g})\end{array}$ & 1375 & 1325 & 1375 & 1325 \\
\hline $\begin{array}{c}\text { Calcium } \\
\text { Lactate } \\
(\mathrm{g})\end{array}$ & 12.5 & 12.5 & 12.5 & 12.5 \\
\hline $\begin{array}{c}\text { DE } \\
\text { (g) }\end{array}$ & 0 & 50 & 0 & 50 \\
\hline $\begin{array}{c}\text { Bacterial } \\
\text { Load } \\
\text { (CFU/blend) }\end{array}$ & 0 & 0 & $2.4 \times 10^{10}$ & $2.4 \times 10^{10}$ \\
\hline
\end{tabular}

\subsubsection{Phase II cracking and compression}

Compression test was conducted in accordance with ASTM C109. After curing for 7 days, a cube from each blend (control and bioconcrete, both with and without DE) was loaded until failure to determine the ultimate load. Then, each control and bioconcrete cube was exposed to $80 \%$ of its respective ultimate load to induce the formation of microcracks. A group of cracked cubes were then immersed in tap water for another week (7 days) to allow the bacteria to begin calcite precipitation and crack healing, while another group of cracked cubes was left in tap water for three weeks ( 21 days). At the end of each period, each cube was loaded to failure to determine the compressive strength after calcite precipitation.

\section{Results}

\subsection{Bacterial isolation}

\subsubsection{Tolerance to alkaline $\mathrm{pH} 14$}

Thirty-five bacterial isolates that can tolerate $\mathrm{pH} 12$ were successfully obtained. These isolates were cultivated in nutrient broth with $\mathrm{pH}$ value 14 in order to reduce the number of isolates and to select the highest tolerability to high $\mathrm{pH}$ values. Eighteen isolates out of the 35 were able to tolerate $\mathrm{pH} 14$. 


\subsubsection{Gram reaction and sporulation}

The 18 isolates that tolerated high $\mathrm{pH}$ levels were stained using Gram stain and malachite green stain and 10 out of 18 isolates were found to be Gram positive spore-formers.

\subsubsection{Urease production}

The 10 Gram-positive spore-forming isolates were tested for their ability to produce urease. Nine out of the ten isolates were able to turn the color of the media from light orange to deep pink, thus indicating positive results for urease production.

\subsubsection{Thermal stability}

The 9 bacterial isolates were cultured in nutrient broth and incubated at $70{ }^{\circ} \mathrm{C}$ for $24 \mathrm{~h}$. Six isolates were able to tolerate high temperature and grow normally. Growth was recorded by observing turbidity of the media after 24 $\mathrm{h}$ at $70{ }^{\circ} \mathrm{C}$. These six isolates were tested further for calcite formation.

\subsubsection{Calcite formation}

Out of the 6 tested isolates only two isolates gave a positive result for calcite production, and these two isolates originated from the legume soil sample and the mud taken from the fish pond in the Dead Sea region.

\subsubsection{Bacterial identification}

The two isolates that gave the sought after results were identified using API $50 \mathrm{CH}$ kit and were found to be Bacillus mycoides, for the bacteria isolated from the soil of legumes, and Bacillus circulans, for the bacteria isolated from the mud of the fish pond.

\subsection{Phase I results}

From the two bacterial types identified, Bacillus mycoides showed more promising results in pilot studies carried out on crack healing and therefore all experiments included in this study were done using Bacillus mycoides. The results of phase I showed that the maximum compressive strength for the control group increased with increasing the curing days which is suspected for normal concrete, where it showed a 5.9\% increase after 21 days. For the bioconcrete, the compressive strength was also obviously increased with curing in comparison with the day of cracking, showing a percentage increase of $15.4 \%$. This was mainly due to calcite precipitation which was obvious in the macroscopic examination of the cubes as shown in Figure 1.
Table 3. Compressive strength of bioconcrete before and after calcite precipitation.

\begin{tabular}{|c|c|c|c|}
\hline Cube ID & $\begin{array}{l}\text { Number of days } \\
\text { after cracking }\end{array}$ & Control & Bioconcrete \\
\hline \multirow{2}{*}{$\begin{array}{l}\text { Compressive } \\
\text { strength of } \\
\text { cracked cubes } \\
\left(\mathrm{N} / \mathrm{mm}^{2}\right)\end{array}$} & $\begin{array}{l}\text { On the day of } \\
\text { cracking }\end{array}$ & 30.94 & 24.88 \\
\hline & $\begin{array}{l}21 \text { days after } \\
\text { cracking }\end{array}$ & 32.76 & 28.72 \\
\hline \multicolumn{2}{|c|}{$\begin{array}{l}\text { Percentage of compressive strength } \\
\text { increase }\end{array}$} & $5.9 \%$ & $15.4 \%$ \\
\hline
\end{tabular}
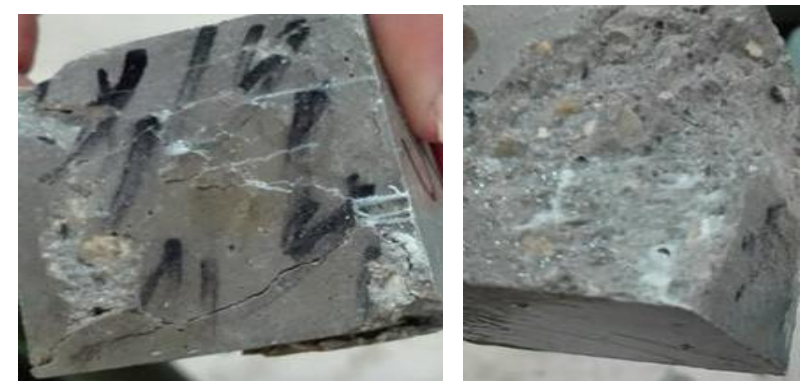

Figure 1. Calcite precipitation on the bioconcrete surface.

\subsection{Phase II Results}

The aim of phase II was to determine the effect of bacterial immobilization using DE on the crack healing process. The compressive strength of the control and bioconcrete cubes was tested after 7 and 21 days of cracking. It was found that the bioconcrete cubes that did not contain DE had higher compressive strengths than the control cubes that did not contain DE; this was in agreement with the results obtained from phase I. As for the bioconcrete that was supplemented with DE, the percentage of increase in its compressive strength after 21 days of cracking was much higher than the percentage of increase in the compressive strength of the control cubes that contained DE. Table 4 and 5 show the results obtained.

Table 4. The compressive strength of the bioconcrete in comparison with the control after 7 and 21 days of cracking.

\begin{tabular}{|c|c|c|c|}
\hline \multirow{2}{*}{ Cube ID } & \multicolumn{3}{|c|}{$\begin{array}{c}\text { Compressive strength } \\
\text { (N/mm2) }\end{array}$} \\
\cline { 2 - 4 } & $\begin{array}{c}\text { At the day } \\
\text { of cracking }\end{array}$ & $\begin{array}{c}7 \text { days after } \\
\text { cracking }\end{array}$ & $\begin{array}{c}21 \text { days after } \\
\text { cracking }\end{array}$ \\
\hline Control - DE & 37.66 & 40.04 & 44.36 \\
\hline $\begin{array}{c}\text { Control + } \\
\text { DE }\end{array}$ & 40.47 & 43.50 & 44.45 \\
\hline $\begin{array}{c}\text { Bioconcrete } \\
\text { - DE }\end{array}$ & 35.82 & 39.43 & 42.13 \\
\hline $\begin{array}{c}\text { Bioconcrete } \\
\text { + DE }\end{array}$ & 39.03 & 44.35 & 46.30 \\
\hline
\end{tabular}


Table 5. The percentage of compressive strength increase after 7 and 21 days of cracking.

\begin{tabular}{|c|c|c|}
\hline \multirow{2}{*}{ Cube ID } & \multicolumn{2}{|c|}{$\begin{array}{c}\text { Percentage of compressive strength increase } \\
(\%)\end{array}$} \\
\cline { 2 - 3 } & $\begin{array}{c}7 \text { days after } \\
\text { cracking }\end{array}$ & $\begin{array}{c}\text { 21 days after } \\
\text { cracking }\end{array}$ \\
\hline Control - DE & 6.3 & 17.8 \\
\hline $\begin{array}{c}\text { Control + } \\
\text { DE }\end{array}$ & 7.5 & 9.8 \\
\hline $\begin{array}{c}\text { Bioconcrete } \\
\text { - DE }\end{array}$ & 10.1 & 17.6 \\
\hline $\begin{array}{c}\text { Bioconcrete } \\
+ \text { DE }\end{array}$ & 13.6 & 18.6 \\
\hline
\end{tabular}

\section{Discussion and conclusion}

The importance of bioconcrete came from the fact that many building material destructions were due to the cracks or the microcracks that forms in the construction materials as a result of several environmental factors. The concept of bioconcrete is based on the self-healing properties of the concrete materials itself: this ability comes from the bacteria that are incorporated within the concrete paste.

When the microcracks develop in the concrete, the bacteria become enriched with oxygen and water and thus are allowed to germinate and start utilizing the nutrients, which include calcium lactate, that are available in the concrete to begin the process of calcite precipitation, which will ultimately be responsible for microcrack healing. Accordingly, there are many studies that are interested in developing bioconcrete using different types of bacterial cells.

In this study, spore-forming, alkaline-tolerant, thermotolerant, urease-producing bacteria were successfully isolated; these characteristics are considered major requirements for bacterial cells to survive and utilize concrete material and to precipitate calcite. Samples from different geographical and environmental sources were tested in order to find the potential isolates and soil in which fava bean legumes were grown was found to be the best source.

Moreover, increasing the dosage of Bacillus bacteria in the concrete matrix was found to have a positive effect on calcite precipitation as more viable bacteria would have a higher cumulative effect on mortar specimens' healing (result not included). Of all the bacterial isolates taken from the various sources, bacteria isolated from the soil of legumes showed the most promising results in calcite precipitation.

Compression test revealed that the compressive strength of the concrete cubes containing bacteria increases more than that of the control specimens after curing, indicating that the healing process carried out by the bacteria increases the compression strength of the material. After determination of the compressive strength for both normal concrete (control) and bioconcrete, it was found that the increase in percentage of compressive strength for the bioconcrete cubes (due to the curing time and calcite precipitation) was higher than that of the control cubes (due to the curing time only).

It is clear from the compressive strength test results that batches with DE have a higher compressive strength than those without DE due to the fact that DE provided a protective environment for bacterial spores from mechanical stress and heat of hydration, and a more supple nutrient storage for calcium lactate was available; this resulted in increased rate of metabolic activity of the bacteria and hence increased calcite precipitation. The addition of $\mathrm{DE}$ in bioconcrete also increased the compressive strength (due to curing time and calcite precipitation).

\section{Future work}

Future studies should cover long term testing as well as exposure conditions. Rapid chloride permeability test should be avoided as it will have significant adverse effect on the transformation of spores to vegetative cells; permeability test using only water should be considered. Further studies should tackle the applicability of using self-healing mechanism for structures immersed in sea water.

\section{Acknowledgement}

This study was funded by king Abdullah II fund for development

\section{References}

1. J.McCORMAC, R.BROWN, Design of Reinforced Concrete, (2013).

2. A.Neville, Properties of concrete, 4 th ed, (1996).

3. G.Souradeep and H.W Kua, Journal of Materials in Civil Engineering, 28(12), 04016165, (2016).

4. H.Jonkers, A.Thijssen, In Proceedings of 2nd International Symposium on Service Life Design for Infrastructure, pp. 4-6, (2010).

5. W.Virginie, H. Jonkers, Cement and Concrete Composites, 33(7), 763-770, (2011).

6. A. AlBughdadi, M. Abou-Zeid. Conference Paper CSCE Annual Conference, (2016).

7. E. Cailleux, V. Pollet, Proceedings of the 2nd International Conference on Self-Healing Materials, Vol. 28. (2009).

8. H.Jonkers, E.Schlangen, Proc. int. FIB symposium, Vol. 1, pp. 425-430, (2008).

9. H.Jonkers, E.Schlangen. Proceedings of FRACOS6: fracture mechanics of concrete and concrete structures, 1821-1826, (2007).

10. A.Fathy, O.Abaza, A.Sharaf, G.Labib, M. Asaad, M., M.Abou-Zeid, E. Fahmy, CSCE General Conference -GEN 56, no. 1, (2014).

11. S. Bang, J. Galinat, V. Ramakrishnan, Enzyme and microbial technology, 28.4-5, 404-409, (2001).

12. N. Degirmenci, A. Yilmaz, Construction and Building Materials, 23(1), 284-288, (2009). 